\title{
Covering mappings and Ulam-Hyers stability results for coincidence problems
}

\section{OANA MLEŞNiŢE}

\author{
ABSTRACT. \\ In this paper, we will present some existence and Ulam-Hyers stability results for coincidence point problems \\ with singlevalued operators. The basic hypothesis in these results is the covering mappings.
}

Acknoledgements. This work was possible with the financial support of the Sectoral Operational Programme for Human Resources Development 2007 - 2013, co-financed by the European Social Fund, under the project number POSDRU/107/1.5/S/76841 with the title Modern Doctoral Studies: Internationalization and Interdisciplinarity.

\section{REFERENCES}

[1] Arutyunov, A. V., Covering mappings in metric spaces and fixed points, Doklady Mathematics, 76 (2007), No. 2, 665-668

[2] Arutyunov, A., Avakov, E., Gel'man, B., Dmitruk, A. and Obukhovskii, V., Locally covering maps in metric spaces and coincidence points, J. Fixed Point Theory Appl., 5 (2009), 105-127

[3] Bota-Boriceanu, M. F. and Petruşel, A., Ulam-Hyers stability for operatorial equations, Analel Univ. Al. I. Cuza, Iaşi, 57 (2011), 65-74

[4] Dmitruk, A. V., Milyutin, A. A. and Osmolovskii, N. P., Lyusternik's theorem and the theory of extrema, Russian Math. Surveys, 35 (1980), No. 6, 11-51

[5] Dontchev, A. L. and Rockafellar, R. T., Regularity and conditioning of solution mappings in variational analysis, Set-Valued Analysis, 12 (2004), No. 1, 79-109

[6] Ioffe, A. D., Metric regularity and subdifferential calculus, Russian Math. Surveys, 55 (2000), No. 3, 501-558

[7] Ioffe, A. D., On perturbation stability of metric regularity, Set-Valued Analysis, 9 (2001), No. 1-2, 101-109

[8] Lyusternik, L. A., On the conditional extrema of functionals, Mat. Sbornik, 41 (1934), 390-401 (in Russian)

[9] Mordukhovich, B. S., Variational analysis and generalized differentiation. I. Basic Theory, Grundlehren Math. Wiss. 330, Springer, Berlin, 2006

[10] Mordukhovich, B. S. and Wang, B., Restrictive metric regularity and generalized differential calculus in Banach spaces, Int. J. Math., Sci., 50 (2004), 2653-2680

[11] Rus, I. A., Remarks on Ulam stability of the operatorial equations, Fixed Point Theory, 10 (2009), No. 2, 305-320

[12] Rus, I. A., Petruşel, A. and Petruşel, G., Fixed point theory, Cluj University Press, 2008

[13] Uderzo, A., A metric version of Milyutin theorem, Set-Valued Var. Anal., 20 (2012), 279-306, DOI 10.1007/s11228-011-0193-9

\author{
DEPARTMENT OF MATHEMATICS \\ BABEŞ-BOLYAI UNIVERSITY \\ KOGĂLNICEANU 1, 400084 CluJ-NAPOCA, ROMANIA \\ E-mail address: oana.mlesnite@math.ubbcluj.ro
}

Received: 29.04.2013; In revised form: 02.04.2014; Accepted: 23.04.2014

2010 Mathematics Subject Classification. 47H10, 54H25.

Key words and phrases. Metric space, coincidence problem, singlevalued contraction, covering mapping, coincidence point, Ulam-Hyers stability. 